\title{
PENGALAMAN FAMILY CAREGIVERDALAM MERAWAT ANGGOTA KELUARGA YANG MENGALAMI GANGGUAN JIWA
}

\author{
Susanti Niman ${ }^{1}$ \\ ${ }^{1}$ STIKes Santo Borromeus \\ Nathanmama11@gmail.com
}

\begin{abstract}
ABSTRAK
Gangguan jiwa merupakan masalah kesehatan yang menyebabkan individu kurang produktif.Family caregiver adalah individu yang memberikan bantuan kepada keluarganya yang mengalami penyakit.Penelitian bertujuan untuk mendeskripsikan fenomena pengalaman family caregiver dalam merawat keluarga yang mengalami gangguan jiwa.Hasil penelitian diharapkan berguna bagi masyarakat dalam meningkatkan kualitas kesehatan.Peneliti menggunakan desain penelitian kualitatif deskriptif dengan pendekatan fenomenologi.Penelitian dilakukan di poliklinik jiwa dewasa, Grha Atma Bandung. Hasil penelitian terhadap 7 informan diperoleh 5 Tema, yaitu : (1) Emosi family caregiver saat pertama kali mengetahui anggota keluarga mengalami gangguan jiwa, (2) Peran keluarga dalam merawat anggota keluarga yang mengalami gangguan jiwa, (3) Tugas keluarga yang dijalani family caregiver dalam membantu proses penyembuhan anggota keluarga yang mengalami gangguan jiwa, (4) Beban yang dirasakan family caregiver saat merawat anggota keluarga yang mengalami gangguan jiwa dan (5) Makna hidup yang dirasakan family caregiver dalam merawat anggota keluarga yang mengalami gangguan jiwa. Family caregiver disarankan mengikuti kegiatan komunitas mengenai gangguan jiwa.
\end{abstract}

Kata kunci :Gangguan jiwa, family caregiver, pengalaman

\section{THE PHENOMENON OF FAMILY CAREGIVER EXPERIENCE IN CARING FOR FAMILIES WITH MENTAL DISORDERS}

\begin{abstract}
Mental disorders are health problems that cause individuals to be less productive. Family caregivers are individuals who provide assistance to their families who have the disease. The study aims to describe the phenomenon of family caregiver experience in caring for families with mental disorders. The results of the study are expected to be useful for the community in improving the quality of health. The researcher used descriptive qualitative research design with phenomenology approach. The study was conducted in adult psychiatric clinic, Grha Atma Bandung. The results of research on 7 informants obtained 5 Themes : (1) Family caregiver emotions when the first time to know family members have mental disorders, (2) The role of families in caring for family members who have mental disorders, (3) Family duties undertaken family caregiver in helping the healing process of family members who have mental disorders, (4) The burden felt by family caregiver when caring for family members who have mental disorders and (5) meaning of life that caregiver family felt in caring for family members who have mental disorders. Family caregiver suggested to follow community activities about mental disorders.
\end{abstract}

Keywords: Mental Disorders, Family caregiver, Experience

\section{PENDAHULUAN}

Gangguan jiwa berdampak pada klien dan keluarganya.Klien akan mengalami gangguan aktifitas sehari-hari, hubungan interpersonal,peran dan sosial. Keluarga mengalami penolakan, stigma, tidak berdaya, kecemasan, kelelahan, penurunan kebutuhan pribadi dan pengembangan sumber daya pribadi (Suryaningrum, 2012). Dampak yang dirasakan oleh keluarga secara umum dengan adanya anggota keluarga yang mengalami gangguan jiwaadalah tingginya beban ekonomi,beban emosi keluarga,stress terhadap perilaku klien, gangguan melaksanakan kegiatan rumah tangga sehari-hari dan keterbatasan melakukan aktivitas sosial karena 
stigma sosial yang muncul pada keluarga tersebut (Ngadiran, Yani \&Daulima, 2010). Beban tersebut membuat keluarga tertekan yang berdampak pada perawatan klien ataupun penyembuhan klien.

Vaugh (1999 dalam Yosef, 2007) memaparkan bahwa keluarga dengan ekspresi emosi yang tinggi (bermusuhan, mengkritik) diperkirakan akan mengalami kekambuhan dengan hasil $57 \%$ kembali dirawat dari keluarga dengan ekspresi emosi yang tinggi dan $17 \%$ kembali dirawat dari keluarga dengan ekspresi emosi yang rendah. Keluarga yang dapat membantu proses penyembuhan secara baik adalah keluarga yang mampu memahami klien dalam berinteraksi, memenuhi kebutuhan, mengawasi pengobatan dan proses membina dalam beradaptasi kembali terhadap lingkungan masyarakat (Fridman,2010). Melakukan hal tersebut dibutuhkan upaya-upaya yang dapat dilakukan keluarga dalam membantu penyembuhan individu tersebut yaitu dengan cara merawat klien.

Upaya yang dilakukan keluarga dalam merawat klien dengan gangguan jiwa menurut Nurhaeni \&Nani (2004) adalah mengenal adanya penyimpangan awal sedini mungkin, mengambil keputusan dalam mencari pertolongan atau bantuan sedini mungkin, menciptakan lingkungan keluarga yang sehat, memanfaatkan sumber yang ada dimasyarakat, melaksanakan program kesehatan, melaksanakan program keagamaan, memantau pemberian obat, mencegah stigma masyarakat seperti melakukan pendekatan pada tokoh masyarakat. Keluarga yang memantau klien secara langsung seharusnya membantu penyembuhan anggota keluarganya akan tetapi, kecenderungan keluargamenjadikan Rumah Sakit Jiwa sebagai tempat pembuangan bagi anggota keluarga dengan gangguan jiwa. Setelah diantar, keluarga tidak pernah dibesuk lagi, klien dianggap sudah menjadi tanggungjawab petugas Rumah Sakit Jiwa, sedangkan keluarga tidak mau tahu tentang keadaan klien(Moersalin, 2009). Memberikan perawatan yang baik pada klien, dibutuhkan anggota keluarga yang memahami, mengerti dan merawat klien mulai dari klien mengalami gangguan sampai dalam proses pengobatan dan rehabilitatif.
Family caregiver adalah individu yang secara umum merawat dan mendukung anggota keluarga yang sakit dalam menjalani kehidupannya (Awad \& Voruganti 2008).Awad dan Voruganti (2010) menambahkan bahwa family caregiver adalah individu yang memberikan bantuan informal dan tidak dibayar kepada anggota keluarga yang membutuhkan bantuan fisik dan emosional.Penelitian Fadli (2013) mengatakan semakin baik sikap dan tingginya dukungan family caregiver semakin berkurang frekuensi kekambuhan klien dan terdapat hubungan semakin meningkat ekspresi emosi family caregiver semakin meningkatkan frekuensi kekambuhan klien ditentukan dengan dukungan family caregiver.

Dukungan family caregiver yang kurang dapat memperburuk seseorang dengan gangguan jiwa, dan kurangnya dukungan keluarga akan menyebabkan ketidakpatuhan klien 2 kali lebih besar dalam mengikuti program terapi (Dimatteo, 2004 dalam Niman, 2013) dan semakin lama merawat, semakin bertambah juga kejenuhan caregiver dalam proses pengobatan klien, keluarga dengan tingkat kejenuhan diperkirakan setelah merawat lebih dari 5 tahun (Swardiman, 2011). Karakteristik caregiver yang baik adalah memiliki kesabaran, kreatifitas dalam mengawasi pengobatan, dan mendukung kegiatan yang membantu pengobatan sedangkan contoh caregiver yang tidak baik adalah yang memasung klien dan tidak melakukan cara dalam proses penyembuhan (Keliat, 2005). Seorang caregiver yang baik harus memiliki kesiapan, dan proses tersebut tentu tidak mudah, dalam proses merawat seorang caregiver pasti akan memiliki berbagai pengalaman seperti perasaan kesulitan, cemas, takut,bimbang atau bahkan perasaan senang karena lebih terlatih dalam merawat atapun juga perasaan bahagia caregiver saat klien mengalami perubahan.

\section{METODE}

Metode yang digunakan adalah kualitatif dengan desain fenomenologi dan proses wawancara semi terstruktur. Informan terdiri dari 7 informan dan 1 key informan. 


\section{HASIL}

Tema yang didapatkan dari hasil penelitian adalah sebagai berikut :

1. Emosi FamilyCaregiver saat mengetahui anggota keluarga mengalami gangguan jiwa.

2. Peran Keluarga

3. Tugas Keluarga

4. Beban Family Caregiver

5. Makna Hidup yang dirasakan Caregiver

\section{PEMBAHASAN}

Emosi family caregiver saat mengetahui anggota keluarga mengalami gangguan jiwa.

Status sehat/ sakit anggota keluarga dan keluarga saling mempengaruhi. Penyakit dalam keluarga mempengaruhi keseluruhan keluarga dan interaksinya, keluarga mempengaruhi perjalanan penyakit dan status kesehatan anggota keluarga. Pengaruh status sehat/sakit terhadap keluarga dengan respon keluarga saling terkait. (Gilliss, Rose, Hallburg \& Martinson, 1989 dalam Friedman,2010). Penyakit yang serius dapat mengakibatkan krisis keluarga, yaitu keluarga mengalami masa ketidakteraturan respon emosional saat mengahadapi stressor masalah kesehatan pada anggota keluarganya.(Hill, 1940 dalam Friedman, 2010).

Emosi adalah reaksi subyektif yang diekspresikan seseorang dan biasanya berhubungan dengan perubahan fisiologis tingkah laku, setiap orang menampilkan reaksi emosi yang berbeda-beda, mereka merasakannya, peristiwa yang terjadi menjadi pencetusnya, dan bagaimana manifestasi kliniknya (Hidayat, 2009).7 informan mengatakan merasa sedih, kaget, dan tak menyangka saat pertama kali anggota keluarga nya didiagnosa mengalami Gangguan Jiwa. Kesedihan yang dirasakan 4, dari 7 informan adalah karena tidak menyangka gejala yang dialami pasien selama ini adalah mengarah ke Gangguan Jiwa. Hal ini terlihat dari ungkapan informan sebagai berikut

"Kaget, pikiran saya..ini kenapa jadi tambah ada yang aneh, cuman sama saya didiemin aja di rumah.. "(Informan 1)
"Kaget neng , sangkaan ibu takut ada perkosaan disana, tapi katanya mah engga ada, jadi bingung ini sakit nya teh sakit apa, jadi naon teh mikir yang lain-lain" (informan 3)

"Ada berapa tahun itu dia gak bilang kan, kadang saya juga kesal kenapa dia tetap diam, terus gak mau dia ngelakuin apapun.." (informan 4)

"mun bahasa sunda nya mah reuwas pan basa itu ibu ga tau, kumaha ieu, terus weh laporan ka $R T / R W$, disuruh ke jalan riau.."(Informan 5)

Gangguan Jiwa adalah penyimpangan dari keadaan ideal dari suatu kesehatan mental yang merupakan indikasi adanya gangguan jiwa.Penyimpangan ini mencakup atas penyimpangan pada pikiran, perasaan dan tindakan. Penderita gangguan jiwa tidak sanggup menilai dengan baik kenyataan, tidak dapat lagi menguasai dirinya untuk mencegah mengganggu orang lain atau menyakiti dirinya sendiri (Kaplan \& Sadock, 1994 dalam Baihaqi, 2005).

Perasaan sedih yang dialami family caregiver saat anggota keluarga sakit menurut Supartini (2000) adalah sebagai berikut a) Perasaan sedih muncul terutama pada saat pasien dalam kondisi kronis seperti gangguan jiwa dan keluarga mengetahui bahwa tidak mempunyai harapan bagi pasien untuk sembuh secara total b) Pada kondisi ini keluarga bisa menunjukkan perilaku isolasi atau tidak mau didekati orang lain, bahkan bisa tidak kooperatif terhadappetugas kesehatan.

Penelitian Iswanti, Suhartini \& Supriyadi (2010) dilakukan yang berjudul koping keluarga terhadap anggota keluarga yang mengalami gangguan jiwa. Salah satunya membahas perasaan yang muncul pada penanggung jawab keluarga yang sakit adalah merasa bingung, khawatir, sedih, merasa bersalah, kecewa dan malu terhadap masyarakat serta merasa keberatan terhadap biaya, sehingga semua masalah diatas merupakan stressor bagi keluarga.

Kesedihan yang dirasakan oleh 1, dari 7 informan adalah kecemasan pada kondisi 
pasien, dan mengalami kesulitan saat ingin membawa ke RS. Hal ini terlihat dari ungkapan Informan yaitu:

"perasaan ibu juga gelisah terus, ya gimana ya, mau ke rumah sakit ga punya uang kitu ibu teh, udah datang ke rumah sakit kampung ga ada reaksi," (Informan 2).

Informan sedih karena sebelum didiagnosa mengalami gangguan jiwa, informan mengalami cemas karena sudah membawa ke rumah sakit kampung tapi tidak ada perubahan, dan karasteristik informan adalah seorang wanita.2 informan lainnya mengatakan sedih saat pertama kali mengetahui anggota keluarga mengalami gangguan jiwa, hal ini didukung oleh penelitian Lemme, (1995, dalam Levenson 2007) bahwa wanita lebih sensitif perasaannya daripada pria. Terkait dengan hasil jurnal tersebut dengan yang didapat memiliki kesamaan bahwa wanita cenderung lebih mengekspresikan perasaannya ditunjukan dengan reaksi non verbal informan saat di observasi oleh peneliti menunjukan reaksi mata berkaca-kaca, bibir gemetar, menunduk dan menampakan raut muka sedih saat menceritakan perasaan nya mengenai perasaan pertama kali saat anggota keluarga di diagnosa mengalami gangguan jiwa dan terdapat pada penelitian ini bahwa semua informan adalah wanita.

\section{Peran Keluarga}

Peran keluarga adalah bagaimana peran yang terjadi pada caregiver dalam merawat anggota keluarga yang sakit karena mengalami gangguan jiwa.Peristiwa hidup situasional yang dihadapi keluarga, tidak dapat dihindari akan mempengaruhi fungsi peran, misalnya karena gangguan kesehatan anggota keluarga. Saat anggota keluarga mengalami gangguan jiwa salah satu atau lebih anggota keluarga mengemban peran pemberi asuhan (Friedman, 2010).

Finley,1989 ; Litman, 1994 dalam Friedman (2010) mengatakan wanita berperan penting sebagai pemimpin kesehatan dan pemberian asuhan pada anggota keluarga yang sakit. 7 informan adalah seorang wanita, yaitu 5 informan yang memiliki peran sebagai Ibu , 1 Informan memiliki peran sebagai isteri, dan 1 informan lainnya memiliki peran sebagai kakak perempuan klien. 5 informan mengalami perubahan fungsi peran di dalam keluarga tersebut, terlihat dari ungkapan informan :

"Adek saya berubah semenjak di tinggal meninggal bapak dan ibu saya..apa-apa aja saya yang ngurus dari awal.." (Informan 1)

Informan 1 adalah kakak dari klien, akan tetapi karena ayah dan ibu dari klien sudah meninggal, maka informan menjalankan peran sebagai ibu dengan merawat klien dan menjalankan peran sebagai ayah dengan bekerja mencari nafkah, ini terlihat dengan ungkapan informan saat ditanya oleh peneliti, kapan awal terjadi klien mengalami sakit, dan pernyataan informan saat di kata kunci adalah perubahan fungsi peran yang mengalami kerepotan saat harus mencari nafkah informan juga harus merawat klien. Friedman (2010) mengatakan Apabila ibu atau isteri mengalami sakit atau tidak dapat menjalankan perannya, maka yang dapat diharapkan menggantikan perannya dalam membantu mendukung keluarga nya adalah anak perempuan tertua.

4, dari 5 informan yang mengalami perubahan fungsi peran, dalam melakukan peran mereka sebagai ibu yang merawat anggota keluarga yang mengalami sakit gangguan jiwa, mereka memiliki kesulitan karena menjalankan beberapa fungsi peran lain yaitu informan 2 yang mengalami kerepotan karena takut saat klien kambuh dan melukai dirinya, sehingga ia terganggu dalam melakukan fungsi sebagai ibu dalam melakukan aktifitasnya sehari-hari sebagai ibu rumah tangga, informan 4 yang memiliki kesulitan saat sebagai nenek harus menjaga cucunya dan disatu sisi ia juga harus menjaga anak perempuannya yaitu klien, informan 5 mengalami perubahan fungsi peran karena ia menjadi membantu suaminya mencari nafkah untuk membantu pengobatan klien, dan akhirnya kesulitan menjalankan perannya saat ia menjadi ibu yang berperan dalam merawat klien tetapi ia juga harus membantu suaminya dalam mencari nafkah lebih untuk pengobatan klien dan informan 6 memiliki perubahan fungsi peran dimana ia mengalami kesulitan saat menjalankan fungsi peran sebagai isteri yang mengurus suami, dan ia harus merawat klien. Kesimpulan yang didapat bahwa perubahan fungsi peran dapat 
terjadi jika sakit yang di derita salah satu anggota keluarga adalah gangguan jiwa.

Friedman, 2010 mengatakan dalam peran Formal istri-ibu antara lain sebagai provider atau penyedia, pengatur rumah tangga, perawat anak baik sehat maupun sakit, sosialisasi anak, memelihara hubungan keluarga paternal dan maternal, peran terapeutik (memenuhi kebutuhan afektif dari pasangan), peran sosial. Saat anak atau suami mengalami sakit gangguan jiwa maka peran Istri-Ibu mendefinisikan gejala, memutuskan alternatif sumber yang tepat, ia juga memegang kendali yang kuat apakah anak atau suaminya akan mendapatkan layanan pencegahan atau pengobatan, serta menjalankan peran informal yaitu mendorong, merangkul anggota keluarga yang sakit untuk mencapai keseimbangan dalam keluarga maka istri-ibu harus menjalankan peran ekstra saat anggota keluarga mengalami gangguan jiwa.

Setiadi (2008) mendefiniskan peran keluarga adalah tingkah laku spesifik yang diharapkan oleh seseorang dalam konteks keluarga.Jadi peran keluarga menggambarkan seperangkat perilaku interpersonal, sifat, kegiatan yang berhubungan dengan individu dalam posisi dan situasi tertentu.Terdapat dua peran yang mempengaruhi keluarga yaitu peran formal dan peran informal Mubarak (2009).Peran formal keluarga adalah peran-peran keluarga terkait sejumlah perilaku yang kurang lebih bersifat homogen, seperti peran ayah, ibu, kakak, adik dan anak.Peran-peran informal bersifat implisit, biasanya tidak tampak, hanya untuk memenuhi kebutuhan-kebutuhan emosional individu atau untuk menjaga keseimbangan dalam keluarga.

Penelitian Nora \& Lidia, 2013 yang berjudul profil keperibadian dan phsycological well beingcaregiver skizofrenia disebutkan bahwa perubahan fungsi peran yang terjadi pada caregiver sebagai isteri, kakak atau adek dan orang tua dipengaruhi oleh stressor yang dirasakan oleh caregiver tersebut.

2 informan lainnya tidak mengalami perubahan fungsi peran, karena mereka mengatakan dapat melaksanakan peran nya secara bersamaan, dan tidak mengalami perubahan fungsi peran di dalam keluarga. Pernyataan tersebut dapat dilihat di hasil transkrip informan. Bahwa informan ke 3 sudah tidak tinggal serumah dengan klien, karena klien tinggal bersama dengan suaminya, sehingga informan dapat menjalani perannya, seperti biasa, begitu juga dengan informan ke 7 , tidak mengalami perubahan fungsi peran karena anak-anak nya sudah dewasa dan mandiri, maka informan hanya merawat suaminya yaitu klien.

\section{Tugas Keluarga}

Tugas keluarga adalah kegiatan yang dilakukan Caregiver di rumah yang dapat membantu proses penyembuhan pasien. Fungsi pemeliharaan kesehatan, keluarga mempunyai peran di bidang kesehatan meliputi (Friedman, 2010): a.Mengenal masalah kesehatan keluarga,b. Memutuskan tindakan kesehatan yang tepat bagi keluarga. Tugas ini merupakan upaya keluarga yang utama untuk mencari pertolongan yang tepatsesuai dengan keadaan keluarga, c. Merawat keluarga yang mengalami gangguan kesehatan. Sering kali keluarga telah mengambil tindakan yang tepat dan benar, tetapi keluarga memiliki keterbatasan yang telah diketahui oleh keluarga sendiri dan d. Memodifikasi lingkungan keluarga untuk menjamin kesehatan keluarga.

7 informan mempertahankan suasana dirumah yang menguntungkan kesehatan dan perkembangan keperibadian anggota keluarga, dengan cara tidak mengacuhkan anggota keluarga yang mengalami gangguan jiwa, tetapi keluarga mau mengikutsertakan anggota keluarga yang mengalami gangguan jiwa dalam berbagai aktifitas yang ada di dalam keluarga tersebut. 4dari 7informan melakukan tugas dengan melibatkan pasien melakukan kegiatan di rumah dengan mengajarkan pasien langsunguntuk melakukan satu kegiatan seperti menyapu, memasak, membereskan tempat tidur, yang mereka latih perlahan yang sampai akhirnya pasien dapat melakukan kegiatan tersebut tanpa disuruh.

Friedman (2010) menyebutkan bahwa salah satu tugas keluarga adalah keluarga tidak mengucilkan anggota keluarga yang sakit atau mengalami gangguan jiwa, dan keluarga mau mengikutsertakan anggota keluarga yang mengalami gangguan jiwa dalam berbagai kegiatan yang ada di dalam keluarga tersebut. Yosef (2007) keluarga merupakan unit yang 
paling dekat dengan klien dan merupakan "perawat utama" bagi klien. Keluarga berperan dalam menentukan asuhan yang diperlukan pasien di rumah. Keberhasilan perawat di Rumah Sakit dapat sia-sia jika tidak diteruskan dirumah yang kemudian mengakibatkan klien harus dirawat kembali (kambuh). Peran serta keluarga sejak awal asuhan di Rumah Sakit akan meningkatkan kemampuan keluarga merawat klien di rumah sehingga kemungkinan dapat mencegah kekambuhan gangguan jiwa.

3 Informan mengatakan melakukan kegiatan dengan memberikan perawatan langsung, karena pasien belum dapat melakukan kegiatan kemandirian bila tidak dibantu oleh informan. 1, dari 3informan ini memberikan perawatan langsung berupa pemenuhan activity daily living,satu yang anggota keluarganya didiagnosa paranoid schizophrenia yaitu informan ke 5 dengan memakaikan baju, menyuapi makan, maka informan dapat memenuhi tugas perawatan klien dalam membantu proses penyembuhan. Tugas keluarga memberikan perawatan langsung kepada anggota keluarga yang sakit yaitu kepada anggota keluarga yang mengalami gangguan jiwa atau yang tidak dapat membantu dirinya sendiri karena cacat atau usianya yang terlalu muda, perawatan ini dapat dilakukan di rumah (Friedman, 2010). Felicia (2013) dalam Sulystiowati (2013) menyebutkan bahwa anggota keluarga yang menderita skizofrenia memerlukan perawatan seperti pemenuhan kebutuhan sehari-hari, masalah activity daily living, serta pemberian pengobatan. Keluarga mempunyai peran besar dalam merawat pasien skizofrenia karena penderita skizofrenia mengalami kemunduran secara kognitif.

\section{Beban Family Caregiver}

Beban Family Caregiver adalah kesulitan yang dihadapi saat merawat anggota keluarga yang mengalami gangguan jiwa, baik itu kesulitan karena faktor luar seperti biaya, ataupun kesulitan yang dirasakan caregiver sendiri baik fisik, maupun psikolgis nya yang dapat menjadi beban pada Caregiver.

4 dari 7informan mengalami beban ganda ( beban objektif dan beban subjektif). Beban objektif yang dirasakan adalah beban biaya, walaupun sekarang masyarakat memakai biaya asuransi pemerintah, akan tetapi biaya transportasi untuk mencapai pelayanan kesehatan menjadi beban untuk beberapa keluarga yang tidak mampu, ditambah dengan beban yang dirasakan caregiver saat merawat yaitu mengungkapkan bahwa anggota keluarganya yang mengalami gangguan jiwa susah diatur, susah nurut, dan sering membuat jengkel, sehingga informanmengalami kesulitan dan menjadi beban tersendiri.

Beban Caregiver keluarga merupakan suatu tolak ukur utama dalam menilai dampak anggota keluarga lain dari perawatan klien gangguan jiwa (Djatmiko, 2004). Beban caregiver dibagi atas dua yaitu beban subjektif dan beban objektif. Beban subjektif caregiver adalah respon psikologis yang dialami caregiver sebagai akibat perannya merawat pasien. Sedangkan beban objektif caregiver yaitu masalah praktis yang dialami oleh caregiver, seperti masalah keuangan, masalah dalam pekerjaan, dan aktivitas sosial (Sukmarini, 2009).

Penelitian Metkono, Pasaribu dan Susilo (2011) membahas bahwa salah satu beban yang dirasakan caregiver adalah pembiayaan transportasi saat ke rumah sakit, dan beban lainnya adalah beban dalam perawatan yaitu munculnya berupa beban stress emosional saat merawat. Beban transportasi dalam mencapai pelayanan kesehatan dilihat dari jarak rumah ke klinik Graha Atma.2 dari 7 informan lainnya merasakan beban akan tetapi beban yang mereka rasakan adalah beban subjektif, informan mengalami kesulitan saat merawat, informan merasa kesal dengan gejala atau tingkah yang ditunjukan oleh pasien, dan membuat mereka selalu memikirkan pasien dan menjadikan nya menjadi beban pikiran. 1informanmerasa kesulitan biaya pengobatan, karena ia melakukan dua jenis pengobatan yaitu pengobatan medisdan pengobatan spiritual yaitu dengan membawa pasien untuk berobat pada ustad yang dipercaya keluarga, dan mengeluarkan biaya untuk pengobatan tersebut. Vijay (2005) mengatakan bahwa perawatan yang dibutuhkan penderita gangguan jiwa menimbulkan dampak yang besar bagi keluarga, yaitu dampak ekonomi yaitu tingginya biaya perawatan yang harus ditanggung. 


\section{Makna Hidup yang dirasakan Caregiver} Makna hidup merupakan proses penemuan suatu hakekat yang sangat berarti bagi individu. Makna hidup dapat dicapai dari nilai kreatif, nilai penghayatan dan nilai bersikap.Nilai kreatif mengilhami individu untuk menghasilkan, menciptakan dan mencapai sukses di dalam suatu pekerjaan.Nilai penghayatan mencakup pengalaman positif seperti cinta dan penghargaan terhadap keindahan. Nilai bersikap membawa seseorang kepada pilihan bersikap terhadap kondisi negatif yang tidak dapat dihindari seperti ketidakadilan (Debats,1993 dalam Kaban, 2011).

5 informan memaknai hidupnya dengan menemukan kekuatan baru sebagai hasil perawatan, dan 2 informan mengatakan memaknai hidup karena merasa puas dengan hasil perawatan yang dilakukan untuk klien. 5 informan mengatakan bahwa merawat anggota keluarga yang mengalami sakit karena gangguan jiwa, menemukan makna hidup menjadi semakin dekat dengan sang pencipta, dan semakin berserah dan yakin semua akan ada berkahnya. Schultz dalam Bastaman (2007) mengatakan kehidupan baru terasa bermakna dan mengandung suatu arti ketika berhadapan dengan situasi yang penuh penderitaan.Individu yang berhasil menghayati bermakna adalah individu yang tetap memiliki gairah saat situasi yang menyenangkan atau dalam penderitaan (Budiharjo, dalam Bastaman 2007).

2 informan lainnya memaknai hidup dengan merasakan kepuasaan atas hasil dalam merawat anggota keluarga yang mengalami gangguan jiwa bahwa klien dapat memiliki perkembangan dan bersyukur karena klien sudah menikah. Frank, 2013 mengatakan kebermaknaan hidup dapat diwujudkan dalam sebuah keinginan untuk menjadi orang yang berguna untuk orang lain, baik itu anak, isteri, keluarga dekat, komunitas dan negara bahkan umat manusia.

\section{SIMPULAN DAN SARAN}

\section{Simpulan}

Family Caregiver saat pertama kali mengetahui anggota keluarga mengalami gangguan jiwa mengalami reaksi emosional sedih, kaget, tidak menyangka, dan sakit hati..Sebagian besar caregiver mengalami perubahan fungsi peran. Tugas keluarga yang dijalani Family Caregiver dalam membantu proses penyembuhan anggota keluarga yang mengalami gangguan jiwa. Beban yang dirasakan keluarga paling banyak adalah beban ganda, dimana caregiver merasakan beban karena biaya dan beban dalam merawat yaitu beban karena merawat anggota keluarga.

\section{Saran}

Family caregiver dapat terus melatih dan merawat klien sampai klien kembali produktif, mampu mengatasi tanda gejala dan mampu memenuhi ADL (activity daily living) secara mandiri, oleh karena itu family caregiver disarankan untuk mengikuti kegiatan komunitas sosial mengenai gangguan jiwa.

\section{DAFTAR PUSTAKA}

Awad, G. A., \& Voruganti, L. (2008). The burden of schizophrenia on caregivers: A review. Pharmacoeconomics. (online) diunduh dari http://repository.usu.ac.id/bitstream/123 456789/14542/1/10E00127.pdf pada tanggal 18 November 2014 pukul 19:20 WIB.

Darwin, Hadikusanto \& Alvira. (2010). Berjudul Beban perawatan dan ekspresi emosi pramurarawat pasien gangguan jiwa. Diunduh dari http://www.e-digital jurnal.com/2014/11/bebab perawatamnindonesia jurnal.html.

Friedman, M. (2009).Buku Ajar Keperawatan Keluarga.Jakarta : EGC.

Fadli, Mulya. (2012). Hasil penelitian berjudul Pengetahuan dan Ekspresi Emosi Keluarga serta Frekuensi Kekambuhan Penderita Skizofrenia.Diunduh dari http://www.google.com/search?q=fadli+ reaksi+emosional+meningkat+dapat+me mpengaruhi+kekambuhan+gangguan $+\mathrm{ji}$ wa + pdf\&ie $=$ utf- $8 \&$ oe $=$ utf$\underline{8 \& a q=t \& r l / / p d f}$. Diunduh tanggal 12 januari 2015.Pukul 08.00 WIB.

Daulima, Novy Helena Chatarina. .(2005). berjudul "Proses Keperawatan Jiwa" 
diunduh dari (Online) http://download.portalgaruda.org/skripsi .php?article $=137413 \&$ val $=5090 \&$ title $=S$ TUDI\%20FENOMENOLOGI:\%20PEN GALAMAN\%20KELUARGA\%20ME NCEGAH\%20KEKAMBUHAN\%20PE RILAKU\%20KEKERASAN\%20PASIE N\%20PASCA\%20HOSPITALISASI $\% 2$ ORSJ. Pada Tanggal 28 November 2014. Pukul 21.00

Iswanti, Suhartini \& Supriyadi (2010). Berjudul Koping keluarga terhadap anggota keluarga yang mengalami gangguan jiwa Diunduh dari http://www.ejurnal.com/2014/11/koping keluarga gangguan jiwa hubungan-antara-bebankeluarga-dengan.htmlpada tanggal 27 Juli 2015.Pukul : 22.30

Levenson, lemme.(2007). Berjudul perbedaan tingkat emosi wanita dan pria. Diunduh dari

http://lib.umpo.ac.id/gunadharma/20\%ju rnal kematangan emosi $20 \%$ pria dan wanitajkptumpo-gdl. pdf pada tanggal 27 juli 2015. Pukul 19.00
Metkono, pasaribu \& susilo.2011. Berjudul Hubungan tingkat pengetahuan dan beban Caregiver dengan perilaku caregiver dalam merawat pasien relaps skizofrenia. Diunduh dari :http://www.ejournalsintcarolus.net//index.php//article/view/p df Tanggal: 12 juli 2015, pukul : 13.00

Sulistyowati, novita. (2013). Berjudul Hubungan pelaksaanaan tugas keluarga dengan kekambuhan skizofrenia di desa Paringan kecamatan jenangan kabupaten ponorogonDiunduh dari http://journal.unair.ac.id/filerPDF/pnj67 608485512full.doc pada tanggal 25 juli 2015. Pukul 22.00. 